\title{
The Phenomenon of Discipline in Professional Attitudes of Beginning Teachers*
}

\author{
Buchtová Tereza, Chudý Štefan, Plischke Jitka \\ Palacky University, Olomouc, the Czech Republic
}

\begin{abstract}
The study outlines basic phenomena of discipline as the basic concepts of professional attitudes of beginning teachers. The contemporary theories of discipline, basic teachers' attitudes, and initial stage of the research of preconceptions focused on dealing with management of discipline of young students in the process of education are introduced here. This paper aims to describe and analyze the concept of discipline among beginning teachers, interpret the contemporary theories of discipline, and describe the ways and means a beginning teacher may handle a lack of discipline among young students. Furthermore, it aims to check the inclusion of discipline in the training of primary school teachers. Content analysis is used as the methodology. In the context of content analysis, texts of study programs with an emphasis on the occurrence of selected features/concepts are investigated. The concepts are formed by the words, phrases, or assertions relating to the area of discipline and its position in the educational training of future teachers.
\end{abstract}

Keywords: discipline, discipline theory, concept of discipline, content analysis

\section{Introduction}

The notion of discipline carries several meanings. Each person perceives discipline in a different way, some as obedience only, some as a code of conduct, and others as habits acquired within personal upbringing. These opinions are to a larger, but also to a lesser extent close to the truth (Makarenko, 1957, p. 31). The word "discipline," as a complex phenomenon, affects people's lives every day in all areas. People encounter this concept either consciously or unconsciously, such as at work, where they adhere to a certain code, or in the family, where they must act as heroes, but they should behave themselves in their spare time too.

However, young students of primary schools encounter this term most often. According to Bendl (2004), discipline can be defined as "conscious adherence to specified standards of conduct" (p. 23). That means the conscious subjecting of oneself to specified standards and conscious respect for the rules, regulations, or provisions. For that reason, the word "conscious" is included in the definition, because it is important that a person is aware of the standards and knows what kind of behavior is required.

From other definitions, we can mention Rotterová (1973), who stated that "discipline in the old school is

\footnotetext{
* Acknowledgments: IGA_PdF_2015_008-The phenomena of discipline and its changes in the process of constituting the professional beliefs of future teachers.

Internal grant of PDF UP: From subjective implicit theories of education to teaching knowledge. The process of constitution of a cognitive framework sciences education in the national and international context.

Buchtová Tereza, Ph.D. candidate, Faculty of Education, Palacky University.

Chudý Štefan, Ph.D., supervisor, Faculty of Education, Palacky University.

Plischke Jitka, Ph.D., lecturer, Faculty of Education, Palacky University.
} 
usually defined by efforts to suppress and break the young student's will, it commands the individual, limits and punishes him/her" (p. 47). This definition talks about unconscious discipline, which is forced. There are many definitions of discipline.

One of the older definitions of discipline comes from Makarenko (1957), who defined discipline as:

Discipline is not to be understood as a means of education only. Discipline is the result of educational process, primarily the result of all the efforts of the very collective of inmates, manifested in all spheres of life: industry, personal, academic, cultural. (p. 30)

Least but not last, it is necessary to mention the definition of discipline made by Uher (1924), who also dealt with problems related to discipline and defined it as follows: "Discipline is either voluntary or forced submission of either an individual or specific society to certain authority, order, either selected upon free will or imposed from the outside" (p. 23). According to Uher, this definition of discipline is reflected in the behavior in a classroom, a gang, as well as in the case of a moral person and also in pedagogical discipline.

\section{Theoretical Background}

The following text discusses the theories (models) of discipline, which must be defined in the context of this paper.

\section{Skinner's Model of Discipline}

Skinner's keynotes are mentioned here as the first theory of discipline. This model includes a new application of Skinner's basic ideas. Skinner himself never proposed a model of school discipline. Other authors took over his ideas and adapted them to control behavior of young students at schools. The following ideas clarify the meaning of Skinner's model:

1. Human behavior is formed upon consequences that follow in the case of each individual immediately after he/she behaves in a certain way;

2. Good behavior of a young student can be systematically reinforced through appropriate guidance;

3. Behavior diminishes if it is not reinforced;

4. Behavior is also weakened by punishment;

5. In the early stages of learning, its constant strengthening leads to the most efficient outcome;

6. Once the desired level is reached by learning, it is maintained the best by occasional reinforcement performed from time to time only;

7. Changes in behavior are implemented in two ways:

(a) The teacher monitors the young student's uncontrollable behavior, when the teacher rewards him/her for his/her behavior, then the young student seems more likely to repeat such behavior.

(b) The teacher monitors the young student's involuntary behavior, when the teacher either ignores or punishes a young student and then he/she rewards a young student who behaves correctly, the misbehaving young student is less likely to repeat his/her behavior.

8. Change in behavior successfully applies different kinds of stimuli. They include social stimuli, such as verbal comments, facial expressions, gestures, graphic stimuli (for example, grades and stars), leisure activities, cooperation with friends, and tangible rewards (such as prizes and diplomas).

Skinner's model can be a powerful model for class teachers, the one that can be easily adjusted and applied to young students of various age and from different environment. 


\section{Glaser's Model of Rational Choice}

One of the other theories of discipline is Glaser's model of rational choice. Glaser's work in the area of school discipline focuses on two spheres. The first area focuses on the provision of such class environment and curricula that motivate young students and reduce inappropriate behavior upon meeting the basic needs of the young students, such as ownership, power, fun, and freedom. The second area helps young students learn appropriate behavior patterns that lead to achieving personal success.

Glasser's keynotes (before the year 1985):

1. Young students are rational beings. They can control their behavior. They choose the way they behave.

2. Good choice leads to good behavior. Bad choice leads to bad behavior.

3. Teachers always have to strive to help young students find the good choice.

4. Teachers who are truly interested in their young students will not accept any excuse for bad behavior.

5. Whether the young students' behavior is good or bad, the appropriate disciplinary measures should always follow.

6. The class rules are obvious and should be observed.

7. Class meetings are an effective means to deal with matters related to the class rules, behavior, and discipline.

\section{Canter's Assertive Discipline}

Another model is the model of Canter's assertive discipline. Assertiveness and firmness are the focal point of Canter's model. If the desired behavior is first invoked in the young students with their help, then they enter the game of well-organized working activities. This model provides a very powerful system of corrective discipline.

Canter's keynotes (Keynotes forming the core of assertive discipline are presented below. These ideas provide a summary of the assertive discipline model):

1. Teachers should insist on appropriate, decent, responsible behavior of young students. Young students need such behavior, their parents want it, the society expects it, and the education process is ineffective without it.

2. With regard to all practical purposes, teachers' failure is identical to the failure in supporting adequate discipline in the class.

3. Many teachers work under the influence of false assumptions about discipline, believing that strict control is inhumane and putting young students under too much pressure. Conversely, proper and firm control is humane and liberating.

4. Teachers have basic educational rights in the class, including:

(a) The right to determine the optimal environment for learning;

(b) The right to request and expect appropriate behavior;

(c) The right to receive assistance from the administrative staff and parents, if necessary.

5. Young students have basic rights in the class as well, including:

(a) The right to have teachers who help reduce inappropriate, self-destructive behavior;

(b) The right to choose the kind of behavior with full awareness of the consequences automatically arising from their choice.

6. Needs, rights, and conditions outlined above can be fulfilled the best by using assertive discipline. Teachers clearly communicate their expectations to young students and follow with relevant consistent acts that do not in any way violate the best interests of young students. 
7. Assertive discipline involves the use of the following behavior patterns. They have to be practiced consistently to be effective:

(a) To express one's expectations clearly;

(b) To be willing to say "I like this" or "I do not like this";

(c) To be consistent when setting expectations and feelings;

(d) To speak by a firm voice;

(e) To maintain eye contact;

(f) To use nonverbal gestures to encourage verbal expression;

(g) To use help, questions and to present and lead by example rather than make claims and requests related to appropriate behavior;

(h) To be assertive when confronting young students, including statements of expectations, warning of possible consequences and stigmatization, and a statement explaining why the act is necessary.

8. Teachers should behave as follows to become more assertive when using discipline:

(a) To practice an assertive way of responding;

(b) To set clear limits and consequences;

(c) To use consistent follow-up procedures;

(d) To construct specific plans of assertive discipline and repeat them mentally;

(e) To write down things not relying solely on memory;

(f) To use the method of "broken turntable" to strengthen expectations;

(g) To ask head teachers and parents to support the efforts to help young students.

The above-mentioned models can be seen as certain theories of discipline that may support and help future teachers, who will have to face discipline, respectively a lack of discipline every day. If future teachers accept these theories, it can be stated that they will be able to maintain discipline in the class.

In relation to the above-mentioned theories, it is worth mentioning some other ways future teachers may handle the disruptive behavior of young students in the class. Ondráček (2001) in his publication mentioned reactions of a teacher to a striking, respectively, disruptive behavior. If a young student behaves in a disruptive manner, it is good for the teacher to know how to respond to such disruptive behavior. If a young student:

1. Demands attention - If the young student behaves disruptively at the lesson and the teacher begins to notice such disruptive behavior and begins to respond to it, the young student understands that he/she has compelled the attention of the teacher and he/she will continue in the disruptive behavior. That is why it is good that the teacher draws attention to the behavior of the young student, for example, by giving the young student homework. This assignment confirms to the young student that the teacher knows about the behavior of the other students, but that he/she does not intend to let this disturbing behavior thwart the lesson. It is good if the teacher pays no notice to other potential disruptive behavior of the young student or communicates with him/her even before the young student begins to behave in such manner.

2. Struggles for power-If the teacher begins to instruct the young student who behaves disruptively how to behave and what he/she should or should not do, the teacher confirms for the young student exactly what the young student wanted, namely, that he/she is fighting for power with the teacher. It is good for the teacher to recognize this behavior based on the struggle for power and make the young student aware of the fact that this struggle for power will not be accepted by the teacher and that the young student has to learn to cope with reality, which may be unpleasant for him/her, and that this teaching situation is one of them. The teacher should 
learn to ignore young student's disruptive behavior based on the struggle for power and should not let the young student provoke him/her.

3. Wants to take revenge-When, in spite of the teacher ignoring it, the young student continues to struggle for power and his/her disruptive behavior escalates, if the young student wants to take revenge, it is good for the teacher to resign to the struggle for power. The teacher should remain calm, not take the attacks of the young student personally, continue with the lesson, despite the fact that the young student tries to take revenge by disruptive behavior. Furthermore, the teacher should try to improve the mutual relationship between the young student that acts disruptively and him/herself. This reaction is difficult, but it can be learned.

The above-mentioned ways in which the teacher can maintain discipline in the class are of importance. Future teachers should realize that they will face a lack of discipline every day, and therefore, it is important that they know about the ways to avoid disruptive behavior of young students and study them from a theoretical point of view. Having acquired the knowledge, they can apply these methods in practice.

One way to maintain discipline among young students is the teacher's authority. The authority of the teacher is also dealt with by Podlahová. A prerequisite for the success of not only pedagogical work, but also for maintaining discipline, is the very authority of the teacher. Podlahová $(2004$, p. 89) indicated that authority is divided into:

(a) Personal: Primary or even natural;

(b) Functional: Professional;

(c) Positional: Secondary;

(d) Formal: Results from the position in the organizational scheme,

(e) Informal: Results of abilities, talent, and education.

Podlahová (2004) also stated that it is necessary to apply these kinds of authority the teachers already know, for example, from their studies, in practice. Types of the authority work together, sometimes one replaces the other. Furthermore, Podlahová $(2004$, p. 90) wrote that it would be ideal if the teacher had informal authority following from good knowledge of the subject, from the level of pedagogical competencies, and also from a good relationship with young students. But it is not so simple, for example, in the case of beginning teachers, because pedagogical competence to maintain discipline (the teacher has the authority) is very complicated, and the teacher has to work on it. Podlahová (2004, p. 90) showed how a teacher can build authority. This building depends on:

1. Expressing the status-The teacher has the right to make decisions and control;

2. Competency of teaching-The teacher must show young students his/her good knowledge of the subject and that he/she can teach it well.

3. Teacher-The teacher's lesson should be well arranged, with a brisk start, and the lesson should have certain momentum directing the young students to activities. Principally, the rules of behavior of young students at the lesson should be defined.

4. Effective and fair solution of the situation, when the teacher has to deal with undesirable behavior of young students.

5. Consistency of actions and words-The teacher should lead by example and be a role model for young students.

This listing helps teachers develop authority. If a teacher really creates authority in relation to young students and maintains it, it is less likely that the young students will not observe discipline. Young students' 
inappropriate behavior is affected by various influences and the authority of the teacher is also one of them. Kyriacou (1996) mentioned a similar way the teacher can build authority. He wrote that the construction of teacher's authority depends on four main factors. Kyriacou (1996, p. 99) listed these four factors as follows:

1. The teacher must reflect his/her status;

2. Teaching must be competent;

3. The teacher must do the job as a manager;

4. The teacher must establish an effective approach to young student's behavior that is undesirable.

Kyriacou (1996) said that these four ways to enable the teacher to create authority and maintain it are closely aligned with the list defining how to create authority, stated by Podlahová above. However, teachers should not automatically assume discipline among students. Podlahová (2004, p. 94) stated that a teacher should first lay the foundation of discipline in such form as solid and logical rules. Furthermore, according to Podlahová (2004, p. 94), these rules are as follows:

1. The teacher has such authority that prevents young students even from the mere idea of indiscipline;

2. The teacher should constantly monitor young students visually, as well as supervise young students' activities. Young students must be aware of the fact that they are being observed by the teacher;

3. The teacher should be a role model for the young students so that the young students want to follow the teacher;

4. The teacher should encourage healthy competition among classmates;

5. The teacher should examine young students not only when announced in advance, but also when it is unexpected;

6. If young students make mistakes, the teacher should correct them immediately;

7. When a young student fails to comply with discipline, the teacher should rebuke him/her and present $\mathrm{him} / \mathrm{her}$ to other young students as a negative example.

It should be noted here that the world has certainly changed a lot since the times of Comenius, ${ }^{1}$ including discipline among young students. The above-mentioned list of rules for teachers stated by Podlahová (2004) still serves to every teacher to know how to prevent indiscipline and how to maintain authority as one of the major influences acting on the young students' behavior. Podlahová (2004) wrote:

Each young student should know what is expected of him/her and what he/she can expect from the teacher. Then he/she does not try to determine the rules of behavior in the class himself/herself, does not perform his/her activity in activities not included in the lesson plan, he/she does not interrupt the work, simply, he/she does not misbehave. (p. 96)

In the case of absence of fixed rules, he/she does not know what to do, he/she is bored or trying to determine own rules. The teacher has to determine the rules. The young students are really important for a peaceful atmosphere in the lesson, for better work of young students and their behavior. If young students do not have rules, there is no reason for them to keep discipline.

The above text defined models of discipline together with authority for several reasons. These models of discipline are an enrichment of the theory focused on discipline. The models also provide a description of the approaches to the definition of the notion of discipline. The above-mentioned models or theories of discipline suggest a methodical processing in terms of approaches, in the form of recommendations, guidelines, and

\footnotetext{
${ }^{1}$ Comenius J. A. (1592-1670), Bishop of Jednota bratrská (Unitas Fratrum), teacher, school reformer, the founder of modern pedagogy.
} 
philosophical-methodological aspects, towards the methodology of educational activities in specific (concrete) environments. Models are basic bearing constructs used in the conceptual elaboration of educational activities and educational counseling, within the framework of system K-6 and K-12, these documents are identical as curriculum and framework education program.

It is good to note that the latest research, involving trainee teachers and their view of the discipline, was processed in 1995 by Šimoník. Bendl also conducted the research. Since then, the subject of a beginning teacher and the discipline has not been developed further.

\section{Methodology}

The second part will deal with content analysis selected as a method for detection and analysis of anchoring of the concept of discipline of beginning teachers and detection of anchoring of discipline in the training of primary school teachers.

Within the content analysis, or text analysis, the research problem was defined: How is discipline anchored in the study programs in the framework of preparation of future primary school teachers? The aim was to determine the anchoring of discipline in the training of future primary school teachers at the secondary school level, tertiary technical school level, and university level. In the context of content analysis, texts of study programs with an emphasis on the occurrence of selected characters/concepts were examined. Concepts were formed by words, phrases, and statements relating to the area of discipline and its position in the educational preparation of future teachers (Krippendorff, 1995).

The basic set of content analysis were the texts and materials related to discipline and its inclusion into the curricula of secondary schools, tertiary technical schools, and universities of the Czech Republic, graduates of which can work at primary schools. The semantic unit was therefore discipline in secondary school, tertiary technical school, and university training of teachers of universities. The characters/concepts examined in the context of content analysis include:

1. Definition of the concept of discipline:
(a) The basic concepts of discipline of future teachers;
(b) Shaping human behavior;
(c) Place, where discipline is anchored;
(d) What does discipline means for teachers.

2. Working with discipline:
(a) Content of work with discipline;
(b) Methods;
(c) Principles for teachers;
(d) Reward/punishment.

3. Desirable/undesirable behavior:
(a) Rules;
(b) Practice;
(c) Defining disciplinary problems;
(d) How to determine a disciplinary problem;
(e) When it is suitable to begin to solve it;
(f) Content of class rules. 
4. Philosophical-methodological concept of discipline:

(a) To look at discipline in terms of power;

(b) The authority of the teacher;

(c) Power;

(d) Assertiveness.

The above features/concepts are important for our research in terms of meaning units, which was specified using the foregoing features/concepts.

The research sample for this research consisted of teachers of public primary schools. Primary school was their first job and practice of these beginning teachers was less than five years.

Questionnaires and interviews were used as data collection methods. The data were subsequently analyzed on the basis of these questionnaires and semi-structured interviews using open coding. ${ }^{2}$ The next step in content analysis, which followed the open coding was finding theoretical relationships among the concepts using the so-called axial coding ${ }^{3}$ (Strauss \& Corbinová, 1999). After axial coding, i.e., finding and specifying relationships among the concepts, another step followed, i.e., the selection of a central concept and formulation of the theory, which is the result of content analysis. Selecting the central concept and formulation of the theory was carried out using selective coding. ${ }^{4}$

The observed data answer the basic research questions: Do elementary school teachers have awareness of discipline that matches the current conception of the curriculum? Does the length of experience have an impact on the awareness of teachers in the area of discipline?

\section{Results}

The data detected by the means of questionnaires with semi-structured interviews and then processed with the help of open coding, axial coding, and selection of the central concept are mentioned in Table 1.

Table 1

Concept: Definition of Discipline

\begin{tabular}{|c|c|c|}
\hline Strengthening behavior using instructions & \multirow{3}{*}{$\begin{array}{l}\text { Shaping behavior through rewards and } \\
\text { punishments }\end{array}$} & \multirow{9}{*}{$\begin{array}{l}\text { The teacher is assertive helping the young } \\
\text { students to shape behavior using rewards } \\
\text { and punishments }\end{array}$} \\
\hline Shaping behavior through consequences & & \\
\hline Use of rewards and punishments & & \\
\hline The young student chooses how to behave & \multirow{3}{*}{$\begin{array}{l}\text { Teacher's help to the young students to } \\
\text { show them how to behave using rules }\end{array}$} & \\
\hline Teacher's help towards the young students & & \\
\hline Rules are commonplace & & \\
\hline Assertive behavior & \multirow{3}{*}{$\begin{array}{l}\text { Assertiveness of the teacher and } \\
\text { educational rights of the young students } \\
\text { and teachers }\end{array}$} & \\
\hline The teacher must not fail & & \\
\hline $\begin{array}{l}\text { The educational rights of young students } \\
\text { and teachers }\end{array}$ & & \\
\hline
\end{tabular}

\footnotetext{
${ }^{2}$ Using open coding created concepts that capture the specific event or events. These concepts are inductively embedded in the data, but on their own are abstract in nature, because they contain ideas, principle, or experience that are applicable across various events or situations.

${ }^{3}$ Using axial coding has been established for the relationship among the concepts and subsequently this relationship was specified in detail. In the case of axial coding, it can not only be said whether concepts have a relationship or cause among themselves, it is necessary to specify them in detail. After this step, the data have changed.

${ }^{4}$ Selective coding is the final phase of coding, which aims to specify, identify, and find the basic, crucial, central categories and conceptualize relations.
} 
The central concept of Table 1 is the sentence that the teacher is assertive, he/she helps the young students shape behavior using rewards and punishments. We can deduct from Table 1 that young students expect from the teacher a particular kind or type of behavior arising from the profession (teaching profession), the teacher is a role model (formal authority) and young students expect his/her "leading role" in the class.

Table 2 shows another concept that was selected in the above-mentioned text and it is working with discipline.

Table 2

Concept: Working With Discipline

\begin{tabular}{|c|c|c|}
\hline Punishments & \multirow{3}{*}{ Punishments and comments } & \multirow{10}{*}{$\begin{array}{l}\text { The teacher gives punishments for } \\
\text { indiscipline behavior, he/she solves the } \\
\text { problem behavior with parents at class } \\
\text { meetings, and draws consequences for the } \\
\text { young students' indiscipline } \\
\text { a }\end{array}$} \\
\hline Observation of behavior, gestures & & \\
\hline Verbal comments & & \\
\hline Interest in the young students & \multirow{3}{*}{ Punishments and meetings } & \\
\hline Disciplinary measures & & \\
\hline Class meetings & & \\
\hline Firm control of the young students & \multirow{4}{*}{$\begin{array}{l}\text { Control of the young students, the teacher } \\
\text { uses gestures and deduces consequences if } \\
\text { the young students do not follow } \\
\text { discipline }\end{array}$} & \\
\hline The rights and obligations, consequences & & \\
\hline Speak in a firm voice & & \\
\hline Nonverbal gestures & & \\
\hline
\end{tabular}

Table 2 clearly shows that the central concept is the teacher who gives punishments for disobedient behavior, solves behavior problems with the parents at parents meetings, and draws certain consequences from the young students' indiscipline that are currently affecting the young students' disobedient behavior. Formation of teaching style is based on a complex activity that is closely connected with the communication with: (a) young students; (b) parents of the young students; and (c) school management.

The teacher regulates his/her activities (educational work with discipline) on the basis of options allowed by the relevant legislation (school rules/laws).

Table 3 shows the concept mentioned above and defines disciplinary problems.

Table 3

Concept: Defining Disciplinary Problems

\begin{tabular}{|c|c|c|}
\hline Early learning phase & \multirow{3}{*}{ The early phase of defining and disciplinary rules } & \multirow{9}{*}{$\begin{array}{l}\text { If the young student violates the } \\
\text { disciplinary rules, the teacher } \\
\text { communicates with him/her timely, } \\
\text { monitors his/her following behavior, } \\
\text { and communicates with parents }\end{array}$} \\
\hline $\begin{array}{l}\begin{array}{l}\text { To monitor impulsive behavior of } \\
\text { the young students }\end{array} \\
\end{array}$ & & \\
\hline Disciplinary rules & & \\
\hline Class rules & \multirow{3}{*}{ The class rules and class meetings } & \\
\hline To monitor the young students & & \\
\hline Solution at class meetings & & \\
\hline To express their expectations & \multirow{3}{*}{$\begin{array}{l}\text { Communication with young students and expressing } \\
\text { expectations of behavior of the young students }\end{array}$} & \\
\hline To prompt and use gestures & & \\
\hline $\begin{array}{l}\text { To control young students with } \\
\text { undesirable behavior }\end{array}$ & & \\
\hline
\end{tabular}

The central concept is disruptive behavior of the young students, which is revealed in time, the teacher communicates with the young students, monitors their behavior, and often communicates with their parents. 
In these concepts, we lack a clear specification of specific disciplinary problems (lack of definition).

Philosophical and methodological concept of discipline was established as the last concept stated in Table 4.

Table 4

Concept: Philosophical and Methodological Concept of Discipline

\begin{tabular}{|c|c|c|}
\hline The authority of the teacher & \multirow{3}{*}{ Authority } & \multirow{10}{*}{$\begin{array}{l}\text { The teacher should be assertive, should } \\
\text { control his/her behavior and maintain } \\
\text { authority in the class }\end{array}$} \\
\hline The teacher ignores behavior & & \\
\hline Cooperation & & \\
\hline Selection of the young students' behavior & \multirow{3}{*}{ Control of behavior } & \\
\hline Control of behavior & & \\
\hline $\begin{array}{l}\text { Help of teachers to the young students to } \\
\text { find the right way to behave }\end{array}$ & & \\
\hline Assertiveness & \multirow{4}{*}{ Authority and assertiveness } & \\
\hline Authority & & \\
\hline Strengthening behavior & & \\
\hline Limits & & \\
\hline
\end{tabular}

The central concept is that teachers should be assertive, should be able to control himself/herself, and should keep authority in the class.

Authority and assertiveness of the teacher make up mutual and complementary perspectives of a theoretical nature. The authority of the teacher takes new shapes and forms. The link from education process to philosophical questions undoubtedly influences considerations of authority as well. Authority as a guarantee of positive values also significantly influences the development of human potential.

\section{Conclusion}

The paper described the concept of discipline from several perspectives. Each author takes a different point of view of discipline. The paper listed and described the models of discipline from which the concepts of discipline were established.

The above-mentioned concepts highlight the personality model and communication, and it is based on personality psychology and cognitive psychology. Models emphasize the specification in terms of education. The categories, such as behavior, control of behavior, formal authority (of the teacher), and the legislative framework of rewards and punishments (class rules, disciplinary rules, and school rules), are defined in detail. These models (theories) help define informal teachers' authority and specify the concept of discipline as a psychologically given category.

Using content analysis, the questions listed above have been answered in the following manner. Primary school teachers are aware of the area of discipline. The length of teachers' practice affects the awareness of discipline, because it is one of the concepts - disciplinary problems were not properly defined.

\section{References}

Andrysová, P., Martincová, J., \& Včelařová, H. (2014). Pedagogical condition at undergraduate teacher preparation. The New Educational Review, 4, 152-165.

Bendl, S. (2004). Disciplinary problems at school (1st ed.). Prague: Triton.

Canter, L., \& Canter, M. (1976). Assertive discipline: A take-charge approach for today's educator. Santa Monica, C.A.: Canter Associates.

Krippendorff, K. (1995). On the reability of unitizing continuous data. Sociological Metodology, 25, 47-76. 
Kyriacou, Ch. (1996). Kličové dovednosti učitele: Cesty k lepšímu vyučování (Key skills of teachers: Ways to improve teaching) (1st ed.). Praha: Portál.

Makarenko, A. S. (1957). O výchově dětí v rodině (The education of children in the family) (6th ed.). Praha: SPN.

Ondráček, P. (2001). Distraction, disobedience and non-cooperation: Ideas for educational work with pupils who behave remarkably disruptive in the classroom. Pardubice: University of Pardubice.

Podlahová, L. (2004). Prvni kroky učitele (First steps to teachers) (1st ed.). Praha: Triton.

Rotterová, B. (1973). Discipline and problems of its formation (1st ed.). Praha.

Skinner, B. F. (1974). About behaviorism. New York, N.Y.: Knopf.

Sommers-Flanagan, J., \& Sommers-Flanagan, R. (2004). Counseling and psychotherapy theories in context and practice. Hoboken, N.J.: John Willey and Sons.

Strauss, A., \& Corbinová, J. (1999). Základy kvalitativniho výzkumu: Postupy a techniky metod zakotvené teorie (Basics of qualitative research: Methods and techniques of grounded theory methods). Boskovice: Albert.

Uher, J. (1924). Problém kázně (The problem of discipline). Prague: The Legacy of Comenius. 